\title{
Synthesis of Zirconia Nanoparticles and Their Ameliorative Roles as Additives Concrete Structures
}

\author{
Masoud Negahdary, ${ }^{1}$ Amir Habibi-Tamijani, ${ }^{2}$ Asadollah Asadi, ${ }^{3}$ and Saeid Ayati ${ }^{4}$ \\ ${ }^{1}$ Young Researchers Club, Marvdasht Branch, Islamic Azad University, Marvdasht, Iran \\ ${ }^{2}$ Department of Chemistry, Islamic Azad University, Mashhad Branch, Mashhad, Iran \\ ${ }^{3}$ Deptartment of Biology, Faculty of Basic Science, University of Mohaghegh Ardabili, Ardabil, Iran \\ ${ }^{4}$ Department of Civil Engineering, Arak Branch, Islamic Azad University, Arak, Iran
}

Correspondence should be addressed to Masoud Negahdary; masoud_negahdary@yahoo.com

Received 26 June 2012; Revised 8 August 2012; Accepted 16 August 2012

Academic Editor: Nurettin Sahiner

Copyright ( $) 2013$ Masoud Negahdary et al. This is an open access article distributed under the Creative Commons Attribution License, which permits unrestricted use, distribution, and reproduction in any medium, provided the original work is properly cited.

We investigated synthesis of zirconia nanoparticles (Nps) and their ameliorative roles as additives concrete structures. Synthesized Zirconia Nps were studied with X-ray diffraction (XRD), UV-visible spectrophotometer, and transmission electron microscope (TEM). We used standard Portland cement in related experiment Concrete Structures. The experimental or E series (E1-E4) mixtures were prepared with different amounts of $\mathrm{ZrO}_{2} \mathrm{Nps}$ with an average particle size of $20 \mathrm{~nm}$. The experimental mixtures were prepared $0.125,0.25,0.5$ and $2.0 \% \mathrm{ZrO}_{2} \mathrm{Nps} /$ cement by weight. The modified cement with $\mathrm{ZrO}_{2}$ nanoparticles was studied with split tensile strength, flexural strength and setting time methods. Final results showed that Zirconia Nps could be used for their Ameliorative roles as Additives Concrete Structures.

\section{Introduction}

Concrete is as essential to our modern world as computers or electricity. In fact it is employed extensively in the construction industry and consumed at a rate of 6 billion tones per year $[1,2]$. Concrete is a mixture of stone and sand held together by a hardened paste of cement and water [3]. When the ingredients are thoroughly mixed they make a plastic mass which can be casted or molded into a predetermined size and shape $[4,5]$. When the cement paste hardens the concrete becomes very hard like a rock. It has great durability and the ability of carrying high loads especially in compression. As it is initially plastic it can be used in various types of constructions [6, 7]. However, conventional concrete suffers from a number of inherent deficiencies, such as its low tensile strength. The cement grains bind together and create a stone-like material called concrete $[8,9]$. Despite cementations materials being the most widely used in building material through the world, its chemical and physical components make the fundamental mechanisms, although its usage is not understood well [10]. Development of new techniques to characterize materials at the nano scale has also provided a unique opportunity for studying cement. Nanoscience and nanotechnologies represent a field of study that is currently attracting a great deal of attention $[11,12]$. The prefix "nano" refers to the nanometer ( $\mathrm{nm}$ ), one billionth of a meter. The unusual mechanical, optical, electrical, and magnetic properties exhibited by materials with dimensions in the range $100 \mathrm{~nm}$ down to around $0.1 \mathrm{~nm}$ (the size of a single atom) can differ markedly from the properties of the same materials at larger dimensions. In recent years, researchers have become increasingly adept at manipulating the shape and size of materials at the nanometer scale and have therefore been able to study and exploit these unusual properties [13]. Nanscience and nanotechnologies provide a perfect field for multidisciplinary research, characterized by increasing collaboration between physicists, chemists, biologists, and engineers. Nanotechnologies offer interesting possibilities of cement based on materials $[14,15]$. As the strength of concrete is based on its nanometer size crystal structure, the usage of Nps as additives is combined with new insights into crystal structure mechanics and provides 
many new ideas for the improvement of cement-based materials [16, 17]. Nano $\mathrm{ZrO}_{2}$ (zirconia) particles have a very low thermal conductivity. They are used in thermal barrier coatings in jet turbines and diesel engines to allow doing operation at higher temperatures. The zirconia crystals exhibit superior mechanical properties such as high strength and flexibility [18]. Heat insulating properties and oxygenion conductivity indicate that zirconia has potential for applying in a wide variety of applications $[19,20]$. Here we used zirconia Nps and their ameliorative roles as additives concrete structures. We hope that this research introduces a new way for increasing stability and resistance of concrete structures.

\section{Materials and Method}

2.1. Reagents. Zirconyl chloride octahydrate purchased from Sigma-Aldrich. Methanol $\left(\mathrm{CH}_{3} \mathrm{OH}\right)$, urea $\left(\mathrm{CH}_{4} \mathrm{~N}_{2} \mathrm{O}\right)$, sulphuric acid $\left(\mathrm{H}_{2} \mathrm{SO}_{4}\right)$ were purchased from Merck. All aqueous solutions were prepared by using doubly distilled water.

2.2. Synthesis of $\mathrm{ZrO}_{2}$ Nanoparticles. The $\mathrm{ZrO}_{2}$ Nps were prepared according to the literature. Initially, $2.58 \mathrm{~g}$ $\mathrm{ZrOCl}_{2} \cdot 8 \mathrm{H}_{2} \mathrm{O}$ and $4.80 \mathrm{~g}$ urea were dissolved in $20.0 \mathrm{~mL}$ $\mathrm{CH}_{3} \mathrm{OH}$ under stirring to form a colorless solution. The solution was transferred to a $20 \mathrm{~mL}$ Teflon-lined stainless steel autoclave, which was heated by $200^{\circ} \mathrm{C}$ and maintained at that temperature for $20 \mathrm{~h}$. The obtained white product was post-treated with sulphuric acid solution $(0.167 \mathrm{mmol})$ and then calcined at $645^{\circ} \mathrm{C}[21,22]$.

2.3. Apparatus for Morphological Studies of Synthesized $\mathrm{ZrO}_{2}$ Nanoparticles. The phase characterization of $\mathrm{ZrO}_{2}$ Nps was performed by means of X-ray diffraction (XRD) using a D/Max-RA diffractometer with $\mathrm{CuK} \alpha$ radiation. The absorbance properties of prepared Nps were measured and recorded by using a TU-1901 double-beam UV-visible spectrophotometer. The surface of $\mathrm{ZrO}_{2} \mathrm{Nps}$ was investigated by the use of a transmission electron microscope (TEM) model DS-720.

2.4. Experimental Main Material of Concrete Structures (Cement). We used Portland cement in related experiment for cement. As you know, Portland cement is a very important and necessary material in concrete structures. The chemical compound compositions of this Portland cement that was used in our research is composed of $55 \%\left(\mathrm{C}_{3} \mathrm{~S}\right), 19 \%\left(\mathrm{C}_{2} \mathrm{~S}\right)$, $10 \%\left(\mathrm{C}_{3} \mathrm{~A}\right), \quad 7 \%\left(\mathrm{C}_{4} \mathrm{AF}\right), 2.8 \% \mathrm{MgO}, 2.9 \%\left(\mathrm{SO}_{3}\right), 1.0 \%$ Ignition loss, and $1.0 \%$ free $\mathrm{CaO}$.

2.5. Preparation Mixture of Cement and $\mathrm{ZrO}_{2}$ Nanoparticles. A total of two series of mixtures were prepared in the laboratory replicates. The control mixtures were made of the natural aggregates: cement and water. The experimental or $\mathrm{E}$ series (E1-E4) mixtures were prepared with different amounts of $\mathrm{ZrO}_{2} \mathrm{Nps}$ with an average particle size of $20 \mathrm{~nm}$. The experimental mixtures were prepared $0.125,0.25,0.5$, and $2.0 \% \mathrm{ZrO}_{2} \mathrm{Nps} /$ cement by weight. The water to binder ratio for all mixtures was set at 0.40 [23]. The aggregates for the mixtures consisted of a combination of crushed basalt and of fine sand, with the $30 \%$ parentage of sand by weight. The binder content of all mixtures was $500 \mathrm{~kg} / \mathrm{m}^{3}$.

2.6. Preparation of Test Specimens. Series E mixtures were prepared by mixing the course aggregates, fine aggregates, and powdered materials (cement and $\mathrm{ZrO}_{2} \mathrm{Nps}$ ) in a laboratory concrete drum mixer. The powdered material was only cement. They were mixed in dry condition for two minutes, and for another three minutes after adding the water. Samples of the fresh concrete were determined immediately to evaluate flexural strength following the mixing procedure. Cylinders with a diameter of $150 \mathrm{~mm}$ and a height of $300 \mathrm{~mm}$ for split tensile strength and cubes with $200 \mathrm{~mm}$ $\times 50 \mathrm{~mm} \times 50 \mathrm{~mm}$ edges for flexural strength tests were cast and compacted in two layers on a vibrating table, with each layer being vibrated for $10 \mathrm{~s}$ [24]. The molds were covered with polyethylene sheets and moistened for $24 \mathrm{~h}$. Then, the specimens were demoded and cured in water at $20^{\circ} \mathrm{C}$ prior to the experimental period. The tensile strength tests of the concrete samples were determined at 5, 10, and 15 days. The reported results were the average of three replicates.

2.7. Investigation Split Tensile Strength of Cement Modified with $\mathrm{ZrO}_{2}$ Nanoparticles. The split tensile test was carried out in accordance to the ASTM C 496-90 standard. After the specified curing period, the concrete cylinders were subjected to split tensile test by using a universal testing machine. Tests were carried out on triplicate specimens and average split tensile strength values were obtained.

2.8. Investigation Flexural Strength of Cement Modified with $\mathrm{ZrO}_{2}$ Nanoparticles. The flexural strength of concrete is used as a structural design criterion and as a general indicator of concrete strength. ASTM C 293 (C-293) determines the flexural strength of concrete specimens by the use of a simple beam with center-point loading. Flexural tests were undertaken in accordance with the ASTM C293 standard. Similar to the tensile tests, flexural tests were carried out on triplicate specimens and average flexural strength values were obtained.

2.9. Setting Time of Cement Modified with $\mathrm{ZrO}_{2}$ Nanoparticles. Setting time of the specimens was regulated according to the ASTM C191 standard. The ASTM C191 method determines the time of setting of hydraulic cement by the means of the Vicat needle.

\section{Results and Discussion}

3.1. X-Ray Diffraction of $\mathrm{ZrO}_{2}$ Nanoparticles. In the XRD pattern (Figure 1) for $\mathrm{ZrO}_{2} \mathrm{Nps}$, the diffraction peaks are absorbed at $2 \theta$ values. The prominent peaks have been utilized to estimate the grain size of sample with the help of Scherrer equation [25] $\mathrm{D}=K \lambda /(\beta \cos \theta)$, where $K$ is constant(0.9), $\lambda$ is the wavelength $\left(\lambda=1.5418 \mathrm{~A}^{\circ}\right)(\mathrm{Cu} \mathrm{K} \alpha), \beta$ is the full width at the half maximum of the line and $\theta$ is the 
TABLE 1: Total specific pore volumes and most probable pore diameters of control and E (1-4) specimens, before and after the addition of different amounts of $\mathrm{ZrO}_{2} \mathrm{Nps}$.

\begin{tabular}{lcc}
\hline Sample designation & Total specific pore volume $(\mathrm{mL} / \mathrm{g})$ & Most probable pore diameter $(\mathrm{nm})$ \\
\hline Control $\left(0 \% \mathrm{ZrO}_{2} \mathrm{Nps}\right)$ & 0.052 & 73 \\
$\mathrm{E} 1\left(0.125 \% \mathrm{ZrO}_{2} \mathrm{Nps}\right)$ & 0.047 & 66 \\
$\mathrm{E} 2\left(0.25 \% \mathrm{ZrO}_{2} \mathrm{Nps}\right)$ & 0.038 & 52 \\
$\mathrm{E} 3\left(0.5 \% \mathrm{ZrO}_{2} \mathrm{Nps}\right)$ & 0.026 & 40 \\
$\mathrm{E} 4\left(2.0 \% \mathrm{ZrO}_{2} \mathrm{Nps}\right)$ & 0.012 & 15 \\
\hline
\end{tabular}

TABLE 2: Porosities, average diameters, and median diameters (volume) of control and E (1-4) specimens, before and after the addition of different proportions of $\mathrm{ZrO}_{2}$ Nps.

\begin{tabular}{lccc}
\hline Sample designation & Porosity $(\%)$ & Average diameter $(\mathrm{nm})$ & Median diameter, volume $(\mathrm{nm})$ \\
\hline Control $\left(0 \% \mathrm{ZrO}_{2} \mathrm{Nps}\right)$ & 12 & 40 & 53 \\
$\mathrm{E} 1\left(0.125 \% \mathrm{ZrO}_{2} \mathrm{Nps}\right)$ & 11.3 & 31 & 48 \\
$\mathrm{E} 2\left(0.25 \% \mathrm{ZrO}_{2} \mathrm{Nps}\right)$ & 9.9 & 20 & 39 \\
$\mathrm{E} 3\left(0.5 \% \mathrm{ZrO}_{2} \mathrm{Nps}\right)$ & 8 & 10.5 & 30 \\
$\mathrm{E} 4\left(2.0 \% \mathrm{ZrO}_{2} \mathrm{Nps}\right)$ & 4.23 & 5 & 13 \\
\hline
\end{tabular}

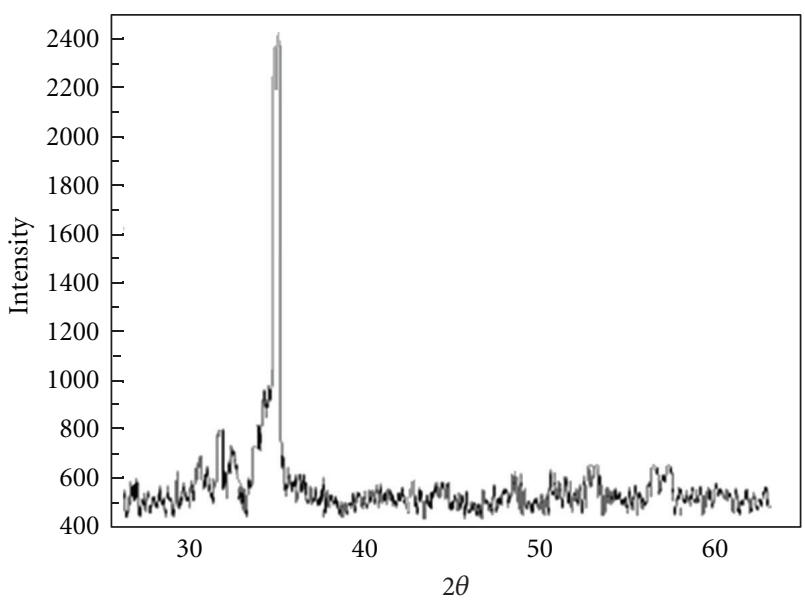

FIGURE 1: XRD pattern for $\mathrm{ZrO}_{2}$ nanoparticles.

diffraction angle. The grain size estimated using the relative intensity peak for $\mathrm{ZrO}_{2} \mathrm{Nps}$ was found to be $20 \mathrm{~nm}$ and increase in sharpness of XRD peaks indicates that particles are in crystalline nature. All different peaks in Figure 1 are related to $\mathrm{ZrO}_{2} \mathrm{Nps}$ and matched to Joint Committee for Powder Diffraction Studies (JCPDS).

3.2. UV-Visible Absorption Spectra for $\mathrm{ZrO}_{2}$ Nanoparticles. The most dramatic property of Nps is the size evolution of the optical absorption spectra. Hence UV-visible absorption spectroscopy is an efficient technique to monitor the optical properties of quantum-sized particles. The UV-visible absorption spectra of $\mathrm{ZrO}_{2} \mathrm{Nps}$ was shown in Figure 2; although the wavelength of our spectrometer is limited by the light source, the absorption band of the $\mathrm{ZrO}_{2} \mathrm{Nps}$ has shown a shift due to the quantum confinement in sample compare with bulk $\mathrm{ZrO}_{2}$ particles. This optical phenomenon indicates that these Nps show quantum size effect [26]. The UV-visible

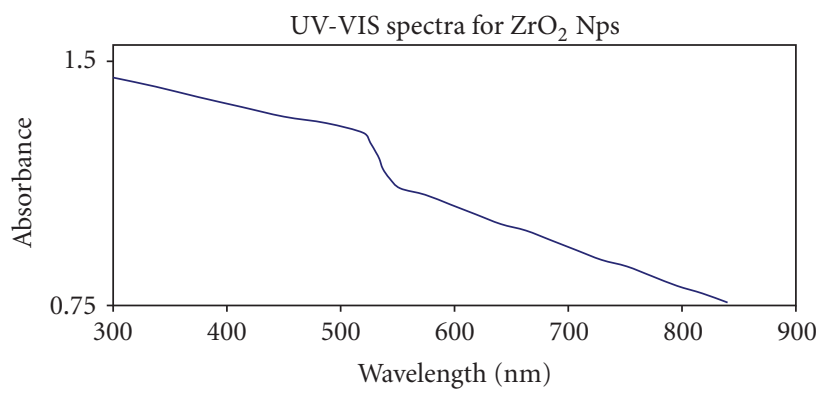

Figure 2: UV-Vis absorption spectra for $\mathrm{ZrO}_{2} \mathrm{Nps}$.

spectrum is in range of 100 to $800 \mathrm{~nm}$. The UV spectrum begins in $100 \mathrm{~nm}$ and ended in $380 \mathrm{~nm}$ and divided to four areas: 1. VUV (100-200 nm), 2. UVC (200-280 nm), 3. UVB (280-320 nm) and 4. UVA (320-380 nm). We used UVB and UVA $(300 \mathrm{~nm})$ in this section. The visible spectrum is in range of 380 to $780 \mathrm{~nm}$.

3.3. TEM Investigation for $\mathrm{ZrO}_{2}$ Nanoparticles. As it is well known, the properties of a broad range of materials and the performance of a large variety of devices depend on their surface characteristics strongly. The average diameter of the synched $\mathrm{ZrO}_{2}$ nanoparticle is about $20 \mathrm{~nm}$ and has a very narrow particle distribution. This statement is illustrated in Figure 3. Figure 3 Shows a TEM picture of the $\mathrm{ZrO}_{2} \mathrm{Nps}$.

3.4. Investigation Effect of $\mathrm{ZrO}_{2}$ Nanoparticles on Strength Properties of Cement. Table 1 shows that by increasing the $\mathrm{ZrO}_{2}$ NPs content to the concrete paste, the total specific pore volumes of concrete can be decreased and the most probable pore diameters of concretes shift to smaller pores and fall in the range of less harmful pores or even harmless pores, which indicates that the addition of $\mathrm{ZrO}_{2} \mathrm{Nps}$ improve the structure of concrete. 
TABLE 3: Split tensile strength of cement modified with $\mathrm{ZrO}_{2} \mathrm{Nps}$.

\begin{tabular}{lccc}
\hline Sample designation & $\begin{array}{c}\text { Split tensile strength }(\mathrm{MPa}) \\
5 \text { days }\end{array}$ & $\begin{array}{c}\text { Split tensile strength }(\mathrm{MPa}) \\
10 \text { days }\end{array}$ & $\begin{array}{c}\text { Split tensile strength (MPa) } \\
15 \text { days }\end{array}$ \\
\hline Control $\left(0 \% \mathrm{ZrO}_{2} \mathrm{Nps}\right)$ & 5 & 5.3 & 5.5 \\
$\mathrm{E} 1\left(0.125 \% \mathrm{ZrO}_{2} \mathrm{Nps}\right)$ & 5.4 & 5.76 & 6 \\
$\mathrm{E} 2\left(0.25 \% \mathrm{ZrO}_{2} \mathrm{Nps}\right)$ & 6 & 6.2 & 6.35 \\
$\mathrm{E} 3\left(0.5 \% \mathrm{ZrO}_{2} \mathrm{Nps}\right)$ & 8 & 8.6 & 9.1 \\
$\mathrm{E} 4\left(2.0 \% \mathrm{ZrO}_{2} \mathrm{Nps}\right)$ & 6.9 & 6.1 & 7.1 \\
\hline
\end{tabular}

Water was used to make the cement paste $+\mathrm{ZrO}_{2} \mathrm{Nps}$ with the ratio of 0.40 .

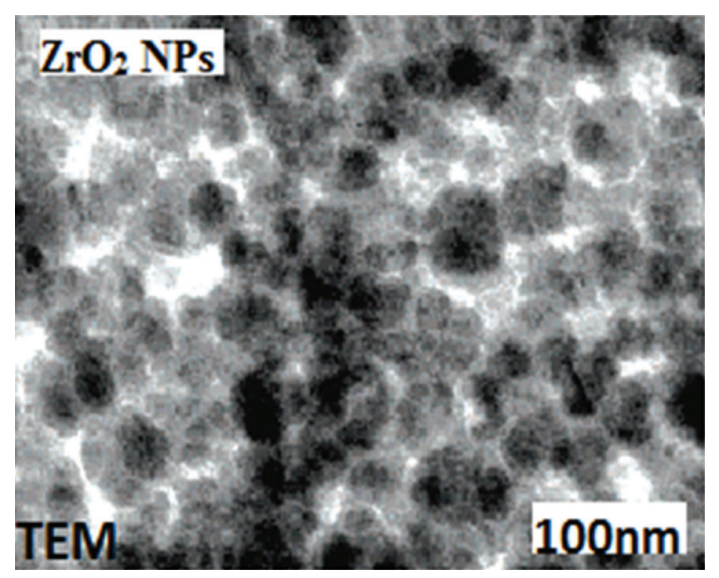

FIGURE 3: TEM images of $\mathrm{ZrO}_{2} \mathrm{NPs}$, with diameter about $100 \mathrm{~nm}$.

Table 2 gives the porosities, average diameters and median diameters, (volume) of the concrete paste before and after the addition of different proportions of $\mathrm{ZrO}_{2} \mathrm{Nps}$. The regularity of porosity is similar to that of total specific pore volume. The regularity of average diameter and median diameter (volume) is similar to that of the most probable pore diameter.

During the early stages (first 5 days) of the hydration process, strength can be affected by the limestone fines that raise the hydration rate of some clinker compounds, since the fines act as nucleation sites of the hydrates formed in the hydration reactions [27]. During the later hydration stages (10 days or more), it can be seen that there are fewer effects on reducing the flexural strength in cement obviously. The pore structure of concrete is the general embodiment of porosity, pore size distribution, pore scale, and pore geometry. The addition of $\mathrm{ZrO}_{2} \mathrm{Nps}$ to the concrete paste can help in decreasing its pore size. In terms of the different effects of pore size on concrete performance, a pore size of $<20 \mathrm{~nm}$ is classified as harmless, while $20-50 \mathrm{~nm}$ is thought to be less harmful and $50-200 \mathrm{~nm}$ is said to be harmful. A pore size of $>200 \mathrm{~nm}$ is thought to be highly harmful [28]. In order to analyze and compare conveniently, the pore structure of concrete is divided into four ranges according to this methodology.

3.5. Split Tensile Strength. The split tensile strengths of the control and experimental (E1 through E4) mixtures were

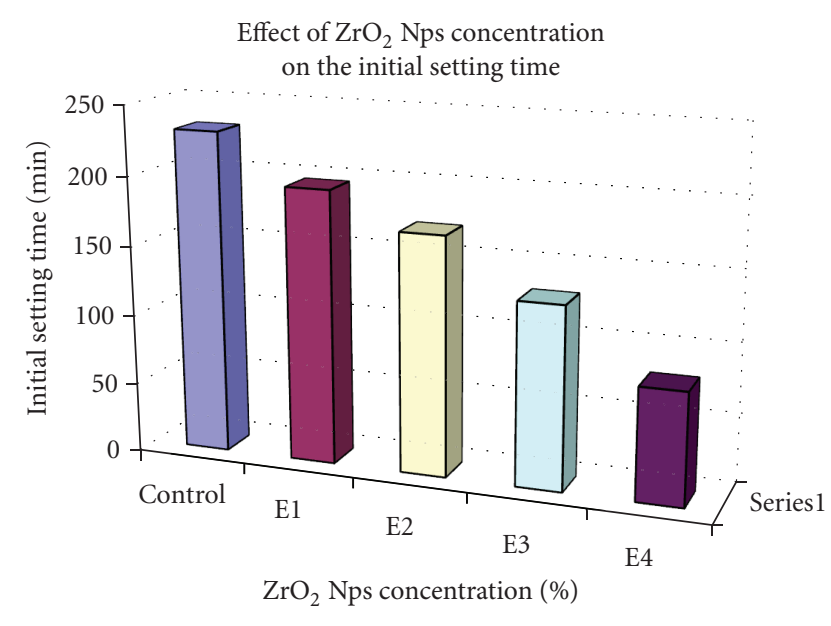

FIgURE 4: Initial setting time of cement modified with $\mathrm{ZrO}_{2} \mathrm{Nps}$.

evaluated by (E1-E4) and without (control) $\mathrm{ZrO}_{2} \mathrm{Nps}$ for 5,10 , and 15 days, as shown in Table 3. Comparison of the results shows that the split tensile strength increased after the addition of $\mathrm{ZrO}_{2} \mathrm{Nps}$ at the concentration of $0.125 \%$ of $\mathrm{ZrO}_{2}$ Nps (E1) after 7 days, and the maximum split tensile strength was observed at $0.5 \% \mathrm{ZrO}_{2} \mathrm{Nps}$ (E3), as compared to that of the control. The 10 and 15-day experiments did not show significantly different results when compared to those of 5 days.

It was also observed that $2.0 \%$ replacement (E4) caused a decrease in the split tensile strength of the experimental cement. This may be due to the fact that the quantity of $\mathrm{ZrO}_{2}$ Nps present in the mixture was higher than the amount required to combine with the liberated lime during the hydration process, thus leading to excess silica leaching out and causing a deficiency in strength as it replaced a part of the cementing material but did not contribute to its strength $[29,30]$. It could be also due to defects generated in the dispersion of Nps causing weak zones. The higher split tensile strength in the E3-blended concrete is due to the rapid consumption of $\mathrm{Ca}(\mathrm{OH})_{2}$, formed during the hydration of Portland cement, especially at the early stage that can be related to high reactivity of $\mathrm{ZrO}_{2} \mathrm{Nps}$. As a consequence, the hydration of cement is accelerated and larger volumes of reaction products are formed. It is also thought that $\mathrm{ZrO}_{2} \mathrm{Nps}$ recover the particle packing density of the blended cement, 
TABLE 4: Flexural strength of cement modified with $\mathrm{ZrO}_{2} \mathrm{Nps}$.

\begin{tabular}{lccc}
\hline Sample designation & $\begin{array}{c}\text { Split tensile strength }(\mathrm{MPa}) \\
5 \text { days }\end{array}$ & $\begin{array}{c}\text { Split tensile strength }(\mathrm{MPa}) \\
10 \text { days }\end{array}$ & $\begin{array}{c}\text { Split tensile Strength }(\mathrm{MPa}) \\
15 \text { days }\end{array}$ \\
\hline Control $\left(0 \% \mathrm{ZrO}_{2} \mathrm{Nps}\right)$ & 5 & 5.3 & 5.5 \\
$\mathrm{E} 1\left(0.125 \% \mathrm{ZrO}_{2} \mathrm{Nps}\right)$ & 5.4 & 5.76 & 6 \\
$\mathrm{E} 2\left(0.25 \% \mathrm{ZrO}_{2} \mathrm{Nps}\right)$ & 6 & 6.2 & 6.35 \\
$\mathrm{E} 3\left(0.5 \% \mathrm{ZrO}_{2} \mathrm{Nps}\right)$ & 8 & 8.6 & 9.1 \\
$\mathrm{E} 4\left(2.0 \% \mathrm{ZrO}_{2} \mathrm{Nps}\right)$ & 6.9 & 6.1 & 7.1 \\
\hline
\end{tabular}

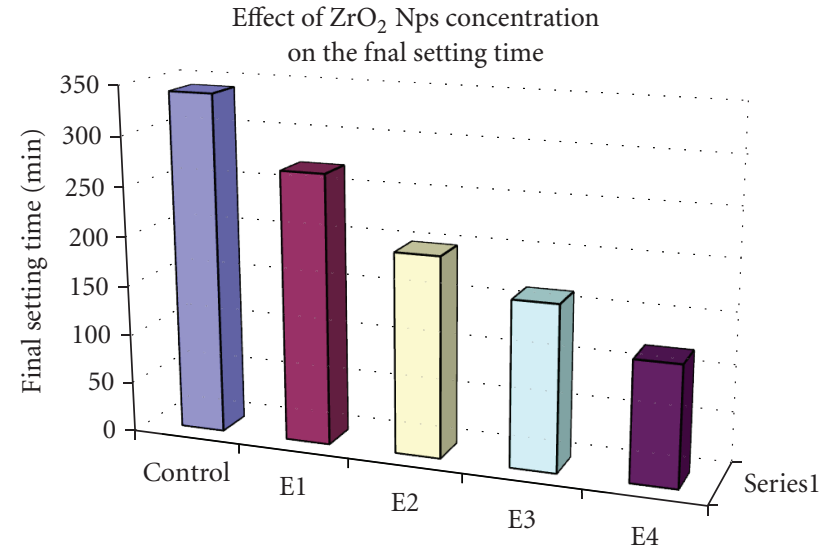

$\mathrm{ZrO}_{2}$ Nps concentration (\%)

FIGURE 5: Final setting time of cement modified with $\mathrm{ZrO}_{2} \mathrm{Nps}$.

leading to a reduced volume of larger pores in the cement paste $[31,32]$. The water to binder ratio for all mixtures was set at 0.40 [23]. This mean that of all mixture (100\%), $60 \%$ was cement paste $+\mathrm{ZrO}_{2}$ Nps and $40 \%$ was water.

3.6. Flexural Strength. The flexural strength results of the experimental (E1-E4) and control specimens are shown in Table 4. Similar to the tensile strength, the flexural strength of the specimens increased by the increased percentage of $\mathrm{ZrO}_{2}$ Nps up to $0.5 \%$ replacement (E3) after 5 days and then decreased (E4) when it compared to the control experiment. It is thought that the increase in flexural strength is due to a rapid consumption of $\mathrm{Ca}(\mathrm{OH})_{2}$, which was formed during the hydration process of Portland cement, especially in the early stages, can be related to high reactivity of $\mathrm{ZrO}_{2} \mathrm{Nps}$. The 10 and 15-day experiments did not show significantly different results when compared to those of 5 days.

The results show that the flexural strength increases by adding $0.5 \%$ Nps (E3) and then decreases. The addition of $0.5 \% \mathrm{ZrO}_{2}$ Nps produced specimens with much higher flexural strength in respect to all the other experimental specimens and also the control group of the concrete. The reduced flexural strength produced by adding $2.0 \% \mathrm{ZrO}_{2}$ $\mathrm{Nps}$ may be due to the fact that the quantity of $\mathrm{ZrO}_{2} \mathrm{Nps}$ existing in the mixture was higher than the amount required to combine with the liberated lime during the process of hydration, thus leading to the leaching out of excess silica and causing a deficiency in strength as it replaces a part of the cementations material but does not contribute to strength. It may also be due to defects generated in the dispersion of Nps, causing weak zones $[33,34]$.

3.7. Setting Time. The experimental results obtained from the initial and final setting times of the cement mortars in the presence of $\mathrm{ZrO}_{2}$ Nps are shown in Figures 4 and 5, respectively. According to Figures 4 and 5, an increase in the volume fraction of Nps caused a significant decrease in setting time. These results indicate that $\mathrm{ZrO}_{2} \mathrm{Nps}$ have an increased speed of hydration reaction than that of the cement itself. This is because of the phenomenon that $\mathrm{ZrO}_{2} \mathrm{Nps}$ are characterized by their unique surface effects, smaller particle size, and higher surface energy [35]. Smaller particle size allows a rapid increase in surface area, leading to a significant and fast rise in the number of superficial atoms. These surface atoms are highly reactive and unstable, which results in a faster reaction speed. Hence, a cautious approach should be taken for the setting time of the cement paste during the utilization of $\mathrm{ZrO}_{2}$ Nps [36].

The mechanism of the Nps in improving the pore structure of concrete can be attributed to the fact that the Nps are uniformly dispersed in concrete and each particle is contained in a cube pattern. And hence, the distance between Nps can be determined. After hydration begins, hydrated products diffuse and envelop the Nps as kernels. If the content of Nps and the distances between them are appropriate, crystallization will be controlled to a suitable state through restricting the growth of $\mathrm{Ca}(\mathrm{OH})_{2}$ crystals by Nps. Moreover, the Nps located in cement paste as kernel can further promote cement hydration due to their high activity. This makes the cement matrix more homogeneous and compact [37].

\section{Conclusions}

Today the applications of nanotechnology are appeared in all fields of science. If nanotechnology can be used as purposeful, useful, and constructive the role of it can be observed in other sciences. Today having firm constructions and Concrete Structures is the main goal of a civil engineering. Given that Portland cement has a key role in most buildings and concrete industry, Cement production with a new combination that will strengthen and have high strength is an imperative aim. Here we got help from nanotechnology. In this study we used $\mathrm{ZrO}_{2} \mathrm{Nps}$ to increase quality and tolerance in concrete structures. Our results confirmed this issue that $\mathrm{ZrO}_{2} \mathrm{Nps}$ 
could be an improvement role in the structure of Portland cement that is main component of concrete structures. The use of Nanoparticles in specific quantities could be caused greatly strength of Portland cement and Concrete Structures and finally this application leads to save the cost. On the other hand, the research on other Nps in construction industry is suggested.

\section{Acknowledgment}

The authors gratefully acknowledge their educational help of Professor Dr. Saeed Rezaei-zarchi from payame Noor University, Yazd province, Yazd, Iran; also Department of Biology and chemistry, payame Noor University Tehran, IRAN supported this research work.

\section{References}

[1] P. C. Hewlett, G. Hunter, and R. Jones, "Bridging the gaps," Chemistry in Britain, vol. 35, no. 1, pp. 40-43, 1999.

[2] A. R. West, Solid State Chemistry and Its Applications, John Wiley \& Sons, Chichester, UK, 1984.

[3] S. L. Sass, The Substance of Civilization, Arcade, New York, NY, USA, 1998.

[4] D. A. Fanella, Design of Low-Rise Reinforced Concrete Buildings: Based on 2009 IBC, ASCE/SEI 7-05, ACI 318-08, International Code Council, Washington, DC, USA, 2009.

[5] American Concrete Institute (ACI), Committee 301, Specifications For Rein Forced Concrete, ACI 301-05, ACI, Farmington Hills, Mich, USA, 2005.

[6] R. G. Blezard, "The history of calcerous cements," in Lea's Chemistry of Cement and Concrete, P. C. Hewlett, Ed., Arnold, London, UK, 4th edition, 1998.

[7] S. P. Shah, "Concrete composites, fiber reinforced," in Handbook of Composite Reinforcements, S. M. Lee, Ed., pp. 155-170, WileyVCH, New York, NY, USA, 1993.

[8] C. Hall, "On the history of portland cement after 150 years," Journal of Chemical Education, vol. 53, no. 4, pp. 222-223, 1976.

[9] R. H. Bogue, "Portland cement and the "plastic" concrete," Journal of Chemical Education, vol. 19, no. 1, pp. 36-42, 1942.

[10] British Standards Institution, BS 4027: Specification for SulfateResisting Portland Cement, BSI, 1996.

[11] R. Feynman, "There's plenty of room at the bottom," in Miniaturization, H. D. Gilbert, Ed., pp. 282-296, Reinhold, New York, NY, USA, 1961.

[12] R. Kurzweil, The Singularity is Near, Viking Press, New York, NY, USA, 2005.

[13] J. J. Ramsden, "What is sustainability?" Nanotechnology Perceptions, vol. 6, no. 3, pp. 179-195, 2010.

[14] W. Banzhaf, G. Beslon, S. Christensen et al., "Guidelines: from artificial evolution to computational evolution: a research agenda," Nature Reviews Genetics, vol. 7, no. 9, pp. 729-735, 2006.

[15] C. Hierold, "From micro- to nanosystems: mechanical sensors go nano," Journal of Micromechanics and Microengineering, vol. 14, no. 9, pp. S1-S11, 2004.

[16] G. A. Ozin and A. C. Arsenault, Nanochemistry: A Chemical Approach to Nanotechnology, RSC Publishing, London, UK, 2005, Encyclopaedic collection of chemical methods of nanomaterials generation.
[17] P. A. Revell, “The biological effects of nanoparticles," Nanotechnology Perceptions, vol. 2, pp. 283-298, 2006.

[18] CG2 Nanocoatings, "Products," 2007, http://cg2nanocoatings .com/antigraff.shtml..

[19] B. M. Reddy, P. M. Sreekanth, Y. Yamada, and T. Kobayashi, "Surface characterization and catalytic activity of sulfate-, molybdate- and tungstate-promoted $\mathrm{Al}_{2} \mathrm{O}_{3}-\mathrm{ZrO}_{2}$ solid acid catalysts," Journal of Molecular Catalysis A, vol. 227, no. 1-2, pp. 81-89, 2005.

[20] R. Mueller, R. Jossen, S. E. Pratsinis, M. Watson, and M. K. Akhtar, "Zirconia nanoparticles made in spray flames at high production rates," Journal of the American Ceramic Society, vol. 87, no. 2, pp. 197-202, 2004.

[21] Y. Chen, S. K. Lunsford, Y. Song et al., "Synthesis, characterization and electrochemical properties of mesoporous zirconia nanomaterials prepared by self-assembling sol-gel method with Tween 20 as a template," Chemical Engineering Journal, vol. 170, no. 2-3, pp. 518-524, 2011.

[22] H. Ranjan Sahu and G. Ranga Rao, "Characterization of combustion synthesized zirconia powder by UV-vis, IR and other techniques," Bulletin of Materials Science, vol. 23, no. 5, pp. 349-354, 2000.

[23] D. D. Bui, J. Hu, and P. Stroeven, "Particle size effect on the strength of rice husk ash blended gap-graded Portland cement concrete," Cement and Concrete Composites, vol. 27, no. 3, pp. 357-366, 2005.

[24] M. H. Huang, S. Mao, H. Feick et al., "Room-temperature ultraviolet nanowire nanolasers," Science, vol. 292, no. 5523, pp. 1897-1899, 2001.

[25] V. A. Drits, D. D. Eberl, and J. Środoń, "XRD measurement of mean crystallite thickness of illite and illite/smectite: reappraisal of the Kubler index and the Scherrer equation," Clays and Clay Minerals, vol. 45, no. 3, pp. 461-475, 1997.

[26] J. Ramsden, Essentials of Nanotechnology, Ventus Publishing ApS, 2009.

[27] A. Marcinek, "Direct characterization of hexamethyl(Dewar benzene) radical cation by electronic absorption spectroscopy," Journal of Physical Chemistry A, vol. 102, no. 40, pp. 7761-7764, 1998.

[28] G. Ye, X. Liu, G. de Schutter, A. M. Poppe, and L. Taerwe, "Influence of limestone powder used as filler in SCC on hydration and microstructure of cement pastes," Cement and Concrete Composites, vol. 29, no. 2, pp. 94-102, 2007.

[29] G. A. Naji, S. AbdulRashid, F. N. A. Aziz, and M. A. M. Salleh, "Contribution of rice husk ash to the properties of mortar and concrete: a review," Journal of American Science, pp. 157-165, 2010.

[30] A. Nazari, S. Riahi, S. Riahi, S. F. Shamekhi, and A. Khademno, "Mechanical properties of cement mortar with $\mathrm{Al}_{2} \mathrm{O}_{3}$ nanoparticles," Journal of American Science, vol. 6, pp. 94-97, 2010.

[31] Q. Ye, Z. Zhang, L. Sheng, and R. Chen, "Comparative study on the pozzolanic activity between nano- $\mathrm{SiO}_{2}$ and silica fume," Journal Wuhan University of Technology, Materials Science, vol. 21, no. 3, pp. 153-157, 2006.

[32] M. N. Al-Khalaf and H. A. Yousif, "Use of rice husk ash in concrete," International Journal of Cement Composites and Lightweight Concrete, vol. 6, no. 4, pp. 241-248, 1984.

[33] S. J. Lee and W. M. Kriven, "Synthesis and hydration study of Portland cement components prepared by the organic steric entrapment method," Materials and Structures/Materiaux et Constructions, vol. 38, no. 275, pp. 87-92, 2005. 
[34] H. Li, M. H. Zhang, and J. P. Ou, "Flexural fatigue performance of concrete containing nano-particles for pavement," International Journal of Fatigue, vol. 29, no. 7, pp. 1292-1301, 2007.

[35] Q. Ye, "The study and development of the nano-composite cement structure materials," New Building Materials, vol. 1, pp. 4-6, 2001.

[36] W. T. Kuo, K. L. Lin, W. C. Chang, and H. L. Luo, "Effects of nano-materials on properties of waterworks sludge ash cement paste," Journal of Industrial and Engineering Chemistry, vol. 12, no. 5, pp. 702-709, 2006.

[37] A. Nazari, S. Riahi, S. Riahi, S. F. Shamekhi, and A. Khademno, "The effects of incorporation $\mathrm{Fe}_{2} \mathrm{O}_{3}$ nanoparticles on tensile and flexural strength of concrete," Journal of American Science, vol. 6, pp. 90-93, 2010. 

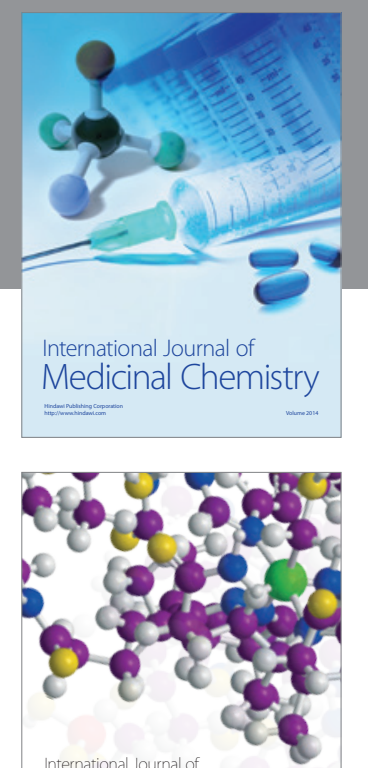

\section{Carbohydrate} Chemistry

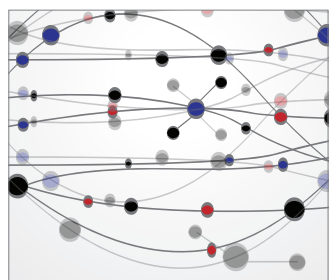

The Scientific World Journal
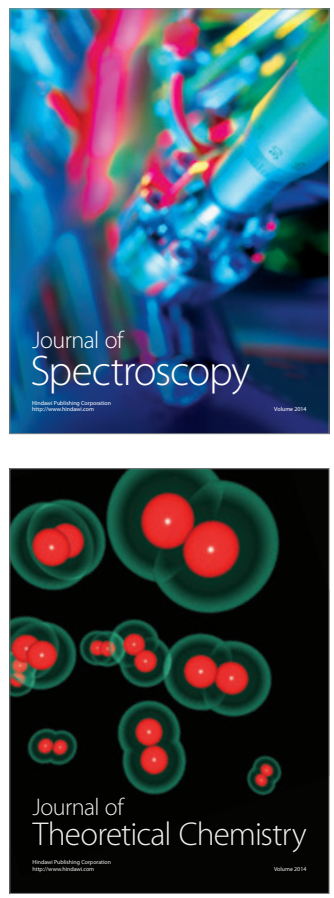
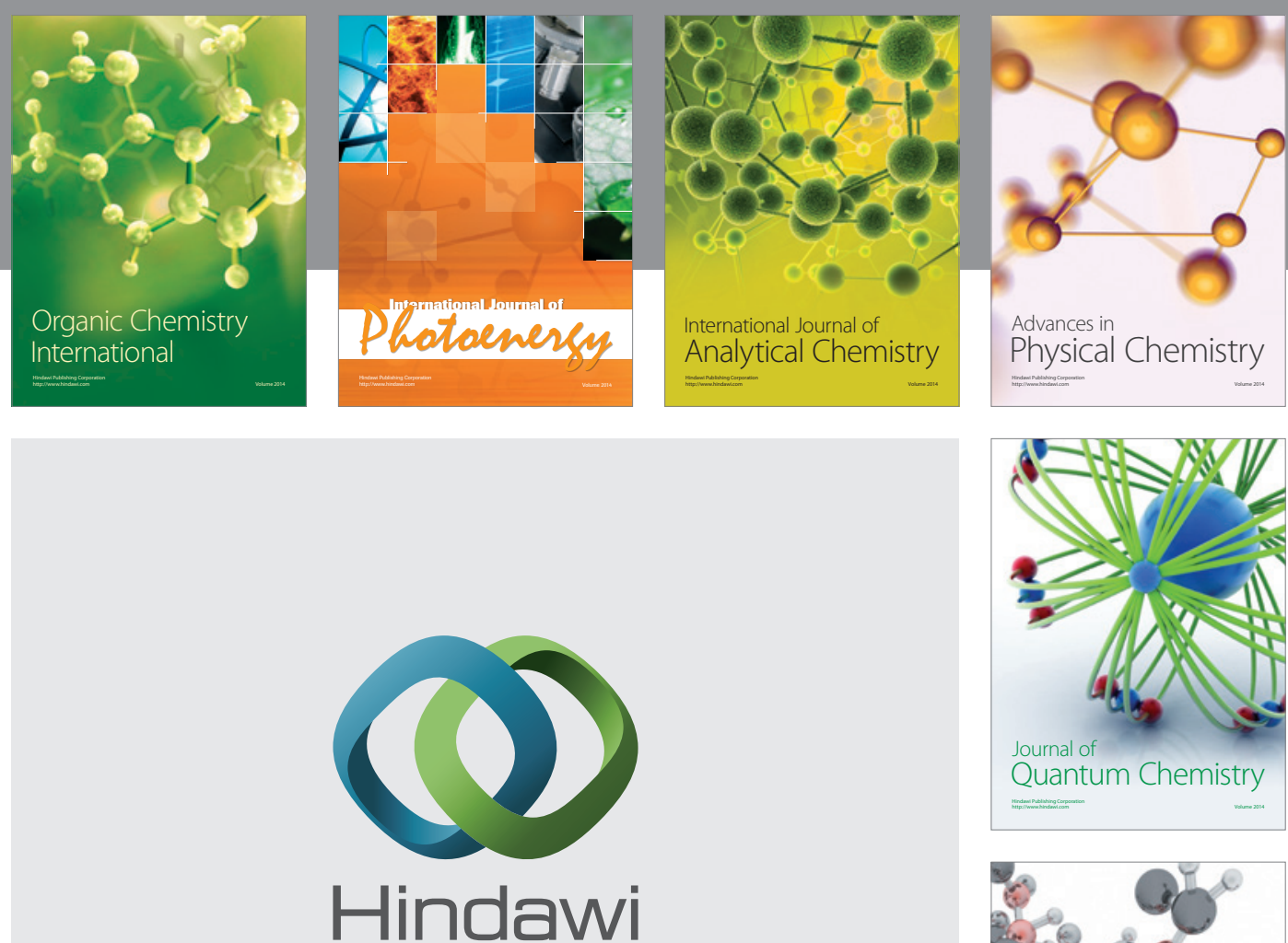

Submit your manuscripts at

http://www.hindawi.com

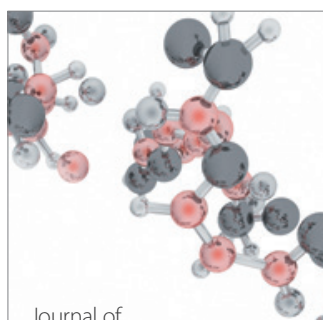

Analytical Methods

in Chemistry

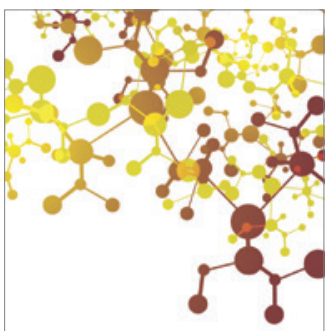

Journal of

Applied Chemistry

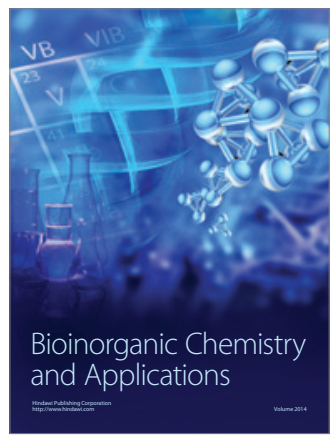

Inorganic Chemistry
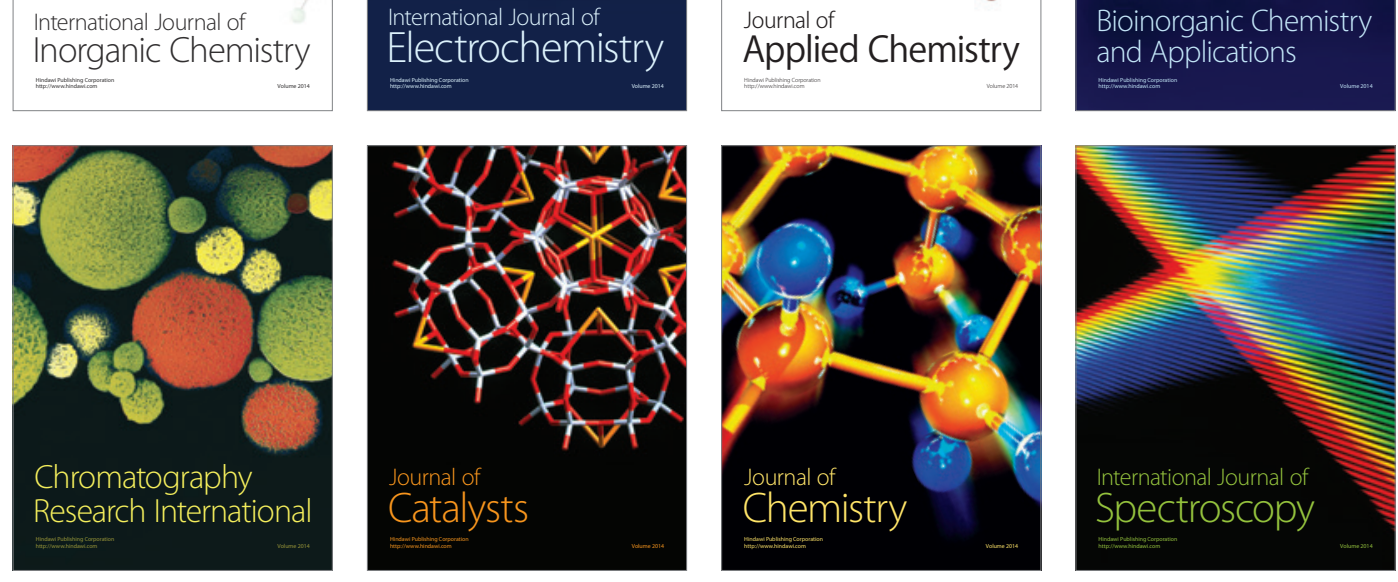